\title{
POTENTIAL OF CORONA SATELLITE IMAGERY FOR 3D RECONSTRUCTION OF ARCHAEOLOGICAL LANDSCAPES
}

\section{POTENCIAL DE LAS IMÁGENES SATELITALES CORONA PARA LA RECONSTRUCCIÓN 3D DE PAISAJES ARQUEOLÓGICOS}

\author{
Jorge Angás ${ }^{a,}$,, Paula Uribe ${ }^{b}$, Manuel Beab ${ }^{b}$ Mercedes Farjas ${ }^{a}$, Enrique Ariñoc, Verónica Martínez- \\ Ferreras $^{\mathrm{d}}$, Josep María Gurt ${ }^{\mathrm{d}}$ \\ a Escuela Técnica Superior de Ingenieros en Topografía, Geodesia y Cartografía, Universidad Politécnica de Madrid, Campus Sur, \\ Autovía de Valencia km.7, 28031 Madrid, Spain. j.angas@usal.es; m.farjas@upm.es \\ b Departamento de Ciencias de la Antigüedad, Universidad de Zaragoza, C/ Corona de Aragon 12, 50019 Zaragoza, Spain. \\ uribe@unizar.es; manubea@unizar.es \\ c Departamento de Prehistoria, Historia Antigua y Arqueología, Universidad de Salamanca, C/ Cervantes s/n, 37002 Salamanca, Spain. \\ argil@usal.es \\ ${ }^{d}$ Department of Ancient History and Archaeology, University of Barcelona, Carrer de Montalegre 6-8, 08001 Barcelona, Spain. \\ vmartinez@ub.edu; jmgurt@ub.edu
}

\begin{abstract}
:
This paper presents a preliminary use of satellite imagery from the CORONA program in the reconstruction of the archaeological landscape of two different sites: Ancient Termez (southern border of Uzbekistan) and Khatm Al Melaha (eastern coast of United Arab Emirates in Kalba area). This analysis constitutes the first step of the work carried out in the field since 2018 at both sites for an analysis of the syntactic interoperability of multi-scale geospatial data for archaeological heritage. The aim of this work was to establish an approach for the use of CORONA satellite imagery for archaeological DEM reconstruction. The objectives of the reconstruction were conditioned for different reasons: in the case of Termez prior to the anthropic transformation of the site in the Soviet - Afghan War and in the case of Khatm Al Melaha prior to the urban, coastal and road transformation. The results have provided uneven data due to the characteristics of the existing imagery: mission, resolution, overlap, orography and different ground control point distribution. This methodology opens a door to the reconstruction of archaeological landscapes that have suffered evident deterioration for different reasons by means of historical aerial imagery in the last 60 years, practically, in some cases, as a primary and unique source for analysing this type of change from the past.
\end{abstract}

Key words: CORONA satellite program, archaeological landscape, Termez (Uzbekistan), Khatm Al Melaha (United Arab Emirates), multi-scale geospatial data, historical aerial photography

\section{Resumen:}

Este artículo presenta un uso preliminar de imágenes satelitales del programa CORONA en la reconstrucción del paisaje arqueológico de dos yacimientos diferentes: la Antigua Termez (frontera Sur de Uzbekistán) y Khatm Al Melaha (costa Este de los Emiratos Árabes Unidos en la zona de Kalba). Este análisis constituye el primer paso del trabajo realizado en campo desde 2018 en ambos yacimientos para un análisis de la interoperatividad sintáctica de datos geoespaciales multiescala para el patrimonio arqueológico. El objetivo de este trabajo ha sido establecer una aproximación sobre el uso de imágenes de satélite CORONA para la reconstrucción arqueológica del MDE. Los objetivos de la reconstrucción estuvieron condicionados por diferentes motivos, en el caso de Termez, previo a la transformación antrópica del yacimiento, por la guerra soviético-afgana y, en el caso de Khatm Al Melaha, previo a la transformación urbana, costera y red de carreteras. Los resultados han proporcionado datos desiguales debido a las características de las imágenes existentes: misión, resolución, solape, orografía y diferente distribución de puntos de control terrestres. Esta metodología abre la puerta a la reconstrucción de paisajes arqueológicos que han sufrido un deterioro evidente por diferentes motivos mediante imágenes aéreas históricas en los últimos 60 años, donde prácticamente en algunos casos, constituye una fuente primaria y única para analizar este tipo de cambios del pasado.

Palabras clave: programa satelital CORONA, paisaje arqueológico, Termez (Uzbekistán), Khatm Al Melaha (Emiratos Árabes Unidos), datos geoespaciales multiescala, fotografía aérea histórica

\section{Introduction}

The use of aerial and terrestrial photogrammetric techniques for the reconstruction of different types of archaeological multi-scale is extremely useful. In the last ten years, the use and combination of 3D laser scanner data with photogrammetric techniques of automatic image correlation have been unified for the reconstruction

‘Corresponding Author: Jorge Angás, j.angas@usal.es 
of Digital Cultural Heritage (DCH). Although it is true that there are different types of application scales, scanners have often not been applied either due to excessive cost or due to different types of magnitudes. Photogrammetric techniques applied to archaeology have been in development for the last 150 years (Stolze 1882) and their use is very varied, from microphotogrammetric techniques to the use of aerial imagery with different types of aircraft or satellite images for archaeological research, including landscape reconstruction (Sevara et al. 2018). If we must trace a beginning in the use of satellite imagery, the CORONA program from the 1960s provides information of great utility for the archaeological scientific community. The advantages of this program are its resolution of up to 1.8 meters, worldwide coverage and accessibility by means of National Archives and Records Administration (NARA). In this sense, the use of this program provides a very useful document to visualize the degree of deterioration that an archaeological site has suffered (Ur 2003; Altmaier and Kany 2002; Goossens et al. 2006). It is even more useful above all in those territories that have undergone a significant change in the last 60 years due to armed conflicts, changes in agriculture land use, urban sprawl, desertification, etc.

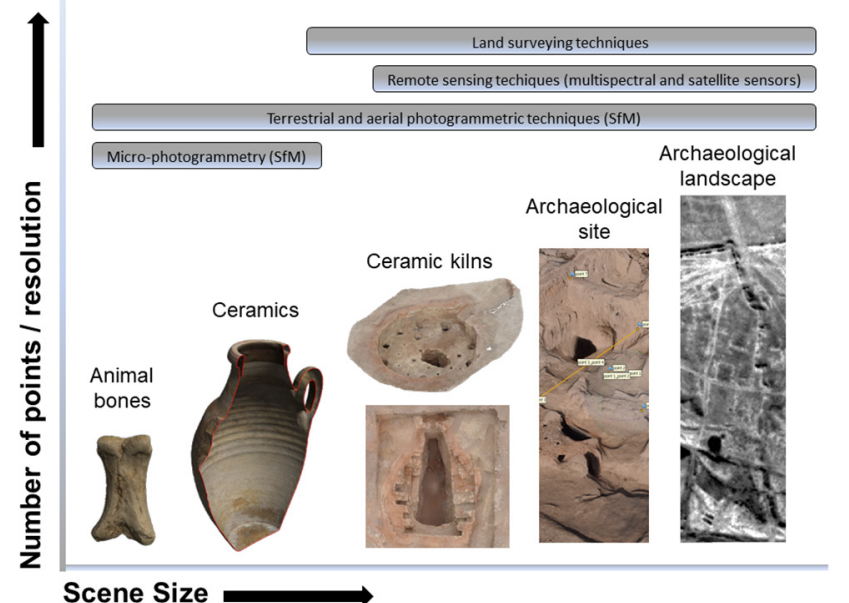

(a)
This preliminary study has used field data from the last five years for the reconstruction of two sites with different geospatial strategies that have undergone very significant changes in the archaeology of the landscape as presented in Figure 1 (Angás et al. 2019a; 2019b). In order to fill this gap in both sites, CORONA satellite imagery was processed, analysed and compared to historical and archaeological data. Although this paper will only focus on the historical landscape analysis part, its use relates to a multi-scale documentation strategy with the utilization of other types of documentation techniques.

The first site in this study is Ancient Termez (Uzbekistan). It is an important historical city on the Silk Road, located in the ancient Bactria region, that was founded after the campaigns of Alexander the Great in the late $4^{\text {th }}$ century BC Yuezhi (Martínez et al. 2014; Gurt et al. 2015). This research requires macro-spatial approaches to accurately record all the archaeological structures and to evaluate the integration and evolution of the pottery workshops into the general topography of the city. As an alternative, the use of drones to reconstruct this area, previous to the Soviet-Afghan War, is not possible due to the location of the archaeological site close to the border area between Uzbekistan and Afghanistan (Fig. 2).

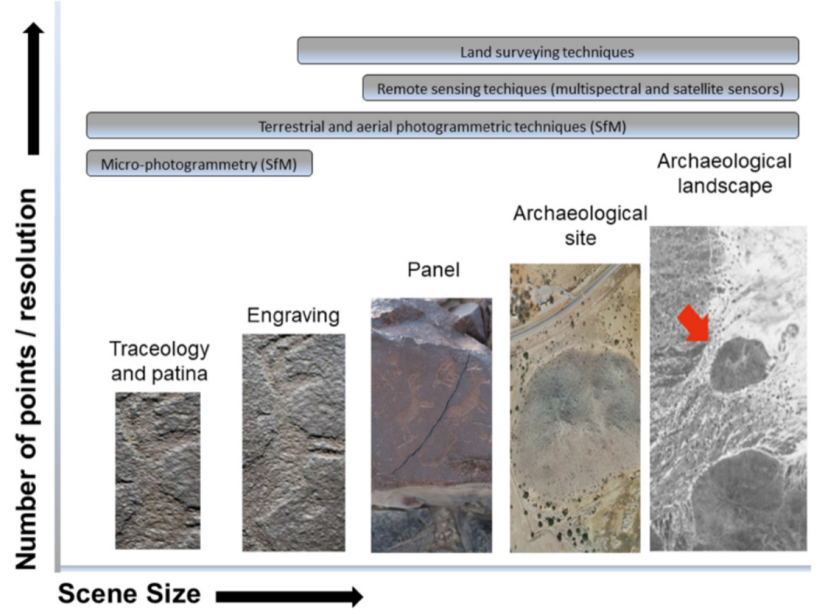

(b)

Figure 1: Geospatial multi-scale strategy documentation and the techniques used in each archaeological site: a) Termez; b) Khatm al Melaha. The CORONA satellite program is related to the last step and its relationship with the knowledge of the archaeological landscape.

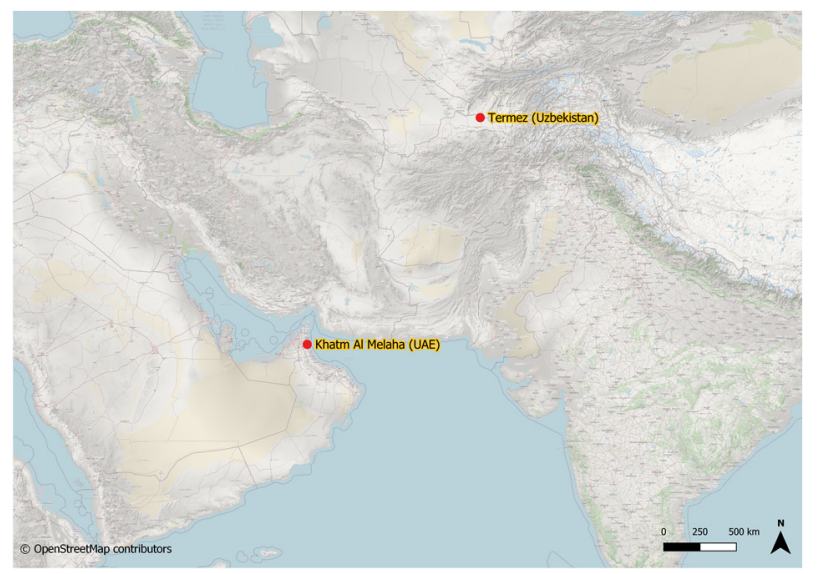

Figure 2: Location of the archaeological sites studied in this work: Termez (Uzbekistan) and Khatm Al Melaha (UAE).
The second example, Khatm Al Melaha (Emirate of Sharjah, United Arab Emirates) is an archaeological site close to the southwest border with the Sultanate of Oman along the Gulf of Oman in Kalba area with a high concentration of open-air rock art engravings. More than 370 rock art engraved motifs, from different chronological phases, were documented on 149 stone blocks with different dimensions and morphologies, distributed along the slope of an isolated 58-metre-high elevation (Fig. 2).

\section{CORONA satellite program}

Despite finding powerful geospatial analysis at scale in archaeology, such as Picterra, the first aerial documentary sources with the greatest global coverage are still used as references today, such as the CORONA satellite program. It is a highly useful source of information due to its high resolution, overlap and worldwide coverage 
in the study of archaeological landscapes of up to 60 years ago. This program replaced the U2 spy planes, which had a much more limited coverage and were also used for historical aerial photography for archaeological purposes (Hammer and Ur 2019). Although President Eisenhower approved the CORONA satellite program in February 1958, the beginning of its use was from the incident on 1 May 1960 when U2 spy plane was shot down by the Soviet Air Defence Force. From this moment CORONA was developed until 1972 with different missions and different resolutions. The stereoscopic images of this program allow the partial reconstruction of archaeological landscapes which in some cases have been lost.

On May 24, 1995, the Central Intelligence Agency and National Air \& Space Museum began the declassification of over 800,000 images taken under the CORONA satellite reconnaissance program by the United States in the 60 s and 70 s during the Cold War from the CORONA programs $(\mathrm{KH}-1$ through $\mathrm{KH}-3$-CORONA-, $\mathrm{KH}-4,4 a$, 4b -MURAL-, KH-5 -ARGON-, KH-6 -LANYARD-). The importance of the CORONA program is key in satellite history since it involved a number of precedents - the first photo-reconnaissance satellite in the world, the first midair recovery of a vehicle returning from space, the first mapping of Earth from space, the first stereo-optical data from space, the first multiple reentry vehicles from space, the first reconnaissance program to fly a hundred missions and the first reconnaissance satellite program to be declassified. The declassification process provided material which was potentially valuable for territorial analysis and interest element detection thanks to the spatial resolution obtained from the continuous satellite improvement. However, the declassification process did not include additional information related to the cameras used nor to the satellite position at the image capture time. Because of that, using these images in a photogrammetrically or a visual analysis based on its digital treatment context is very difficult. Nevertheless, CORONA imagery is one of the best alternatives for images and cartographic resources lacking in places where it has not been developed for different reasons.

The CORONA program was declassified in three different periods (1996, 2002, 2013) with some exceptions:

- $\quad$ Declass 1 (1996) = Corona, Lanyard, \& Argon Missions - KH1 thru KH6: 1960 - 1972.

- Declass 2 (2002) $=\mathrm{KH}-7$ and $\mathrm{KH}-9$ Global Camera Photos: $1963-1980$.

- Declass 3 (2013) = USGS Subset of Hexagon Missions - KH-9: 1971 - 1984.

The imagery provided by the CORONA program has been widely used in recent years in different fields such us urban sprawl, disaster risk (Fekete 2020), geomorphology, land-use, coastline and forest cover change, DEM reconstruction (Galiatsatos 2004; Galiatsatos et al. 2008; Schmidt et al. 2001) and cultural heritage (Watanabe et al. 2017). Although on many occasions it is not sufficiently clear what the data processing flow has been with respect to the results obtained.

\section{Fieldwork}

The fieldwork activities represent the fundamental part both in the acquisition of multi-scale data and in the subsequent verification of the results.

Each archaeological site has undergone different treatment and the documentation has been adapted to these idiosyncrasies.

The coordinate systems used are the following:

- $\quad$ Termez = EPSG: 3857 WGS84.

- Khatm al Melaha = EPSG 32640 UTM zone 40N EPSG:32640.

The common elements between fieldwork activities and images have been to take current benchmarks that have lasted for at least 50 years on the ground. These can be synthesised in old constructions, irrigation channels and any easily identifiable singular elements on the ground that have lasted until today.

Following the above indications, different types of Ground Control Points (GCPs) have been taken with a GNSS combination between Leica GNSS1200 static mode and Leica Zeno GG04, with a precise global positioning system: Precise Point Positioning (PPP) with Spot Prime subscription service, which provides great versatility with an approximate error of 15 centimeters and a convergence time of 20 minutes. The great advantage of this system is that it provides us with real-time high accuracy positioning in regions without an Internet connection, reference network or a local reference station as presented in Figure 3.

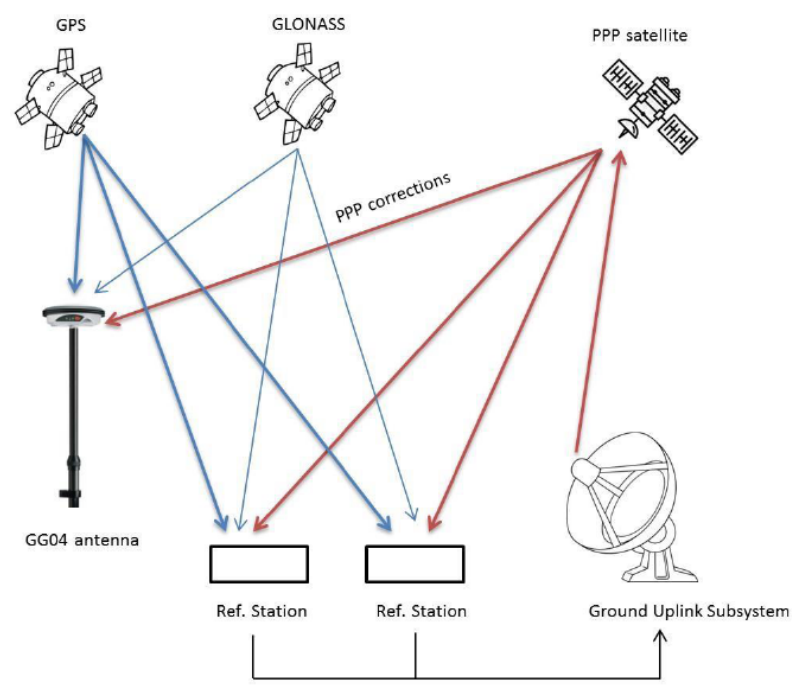

Figure 3: Precise Point Positioning Infraestructure used in GCPs strategy.

However, this system has some limitations in the Spot service. The Precise Point Positioning satellites are geostationary and therefore it is possible to acquire at least one satellite almost anywhere in the world. Nevertheless, obstructions may occur that prevent a correct calculation or the complete loss of satellite signal for which it is necessary to restart the whole process. 


\section{Methodology}

Once the Ground Contol Points have been obtained either by surveying PPP techniques or by means of a selection strategy of those common elements between the CORONA imagery and their current presentation, the corresponding images have been downloaded and classified (Fig. 4).

\begin{tabular}{|c|c|c|c|c|c|c|c|c|}
\hline Entity ID & Date & Mission & $\begin{array}{c}\text { Camera } \\
\text { Resolution }\end{array}$ & $\begin{array}{c}\text { Image } \\
\text { and filum } \\
\text { type }\end{array}$ & Stereo & $\begin{array}{c}\begin{array}{c}\text { Stereo } \\
\text { type }\end{array} \\
\end{array}$ & $\begin{array}{l}\text { GSD } \\
\text { Nadir }\end{array}$ & Used for \\
\hline DZB00403800056H01 1001 & \begin{tabular}{|l|l|l|l|l|l|l|}
087 \\
\end{tabular} & 4038 & $\begin{array}{l}\text { KH-7 High } \\
\text { Resulution } \\
\text { Surveillance }\end{array}$ & $\begin{array}{l}\text { Black and } \\
\text { White, } \\
\text { inch by } \\
\text { variable }\end{array}$ & No & & $0,60 \mathrm{~m}$. & $\begin{array}{l}\text { Archaeology } \\
\text { interpretatioo }\end{array}$ \\
\hline $\begin{array}{l}\text { DS1029-2102DF114 } \\
\end{array}$ & \begin{tabular}{|l|l|l|l|l|l|l|}
0966 \\
\end{tabular} & $1029-2$ & $\begin{array}{l}\text { Stereo } \\
\text { Medium }\end{array}$ & $\begin{array}{c}\text { Black and } \\
\text { White, } \\
\text { 70mm } \\
\text { Panoramic }\end{array}$ & Yes & Forward & $2,7 \mathrm{~m}$. & $\begin{array}{l}\text { A Archaeology } \\
\text { interpretatition }\end{array}$ \\
\hline DZB1210-500127L011001 & $12 / 07 / 1975$ & $1210-5$ & $\begin{array}{l}\text { KH-9 } \\
\text { Lower } \\
\text { Resolution } \\
\text { Mapping }\end{array}$ & $\begin{array}{l}\text { Black and } \\
\text { White; } \\
\text { inch }\end{array}$ & No & & $6 \mathrm{~m}$. & $\begin{array}{l}\text { Archacology } \\
\text { interpretation }\end{array}$ \\
\hline DS1012-1039DA163 & 20/10/1964 & $1012-1$ & $\begin{array}{l}\text { Stereo } \\
\text { Medium }\end{array}$ & $\begin{array}{l}\text { Black and } \\
\text { white, } \\
700 m \text {, } \\
\text { Panoramic }\end{array}$ & Yes & Afterward & $2,7 \mathrm{~m}$ & $\begin{array}{l}\text { Photogrammetry } \\
\text { and } \\
\text { Archacology } \\
\text { interectation }\end{array}$ \\
\hline DS1012-1039DF157 & $20 / 10 / 1964$ & $1012-1$ & $\begin{array}{l}\text { Stereo } \\
\text { Medium }\end{array}$ & $\begin{array}{l}\text { Black and } \\
\text { White, } \\
\text { 7onmm } \\
\text { Panoramic }\end{array}$ & Yes & Forward & $2,7 \mathrm{~m}$ & 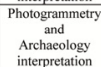 \\
\hline DS1021-2087DA004 & $2405 / 1965$ & $1021-1$ & $\begin{array}{l}\text { Stereo } \\
\text { Medium }\end{array}$ & $\begin{array}{l}\text { Baluramile } \\
\text { Black and } \\
\text { 7hite, } \\
\text { Ponmmic } \\
\text { Panoramic }\end{array}$ & No & Afterward & $2,7 \mathrm{~m}$ & 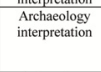 \\
\hline DS1031-2167DF155 & 18/04/1966 & $1031-2$ & $\begin{array}{l}\text { Stereo } \\
\text { Medium }\end{array}$ & $\begin{array}{l}\text { Black and } \\
\text { White. } \\
70 m \text { m } \\
\text { Panoramic }\end{array}$ & Yes & Forward & $2,7 \mathrm{~m}$ & $\begin{array}{l}\text { Archaeclogy } \\
\text { interpretation }\end{array}$ \\
\hline
\end{tabular}

Figure 4: Example of classification of declassified CORONA images that have been used for the Termez site.

Data can be accessed from the USGS EROS Archive through the National Archive Records and Administration (NARA) (Table 1). Each zone corresponds to different missions, film acquisition periods and ground resolution (Figs. 4 and 5).

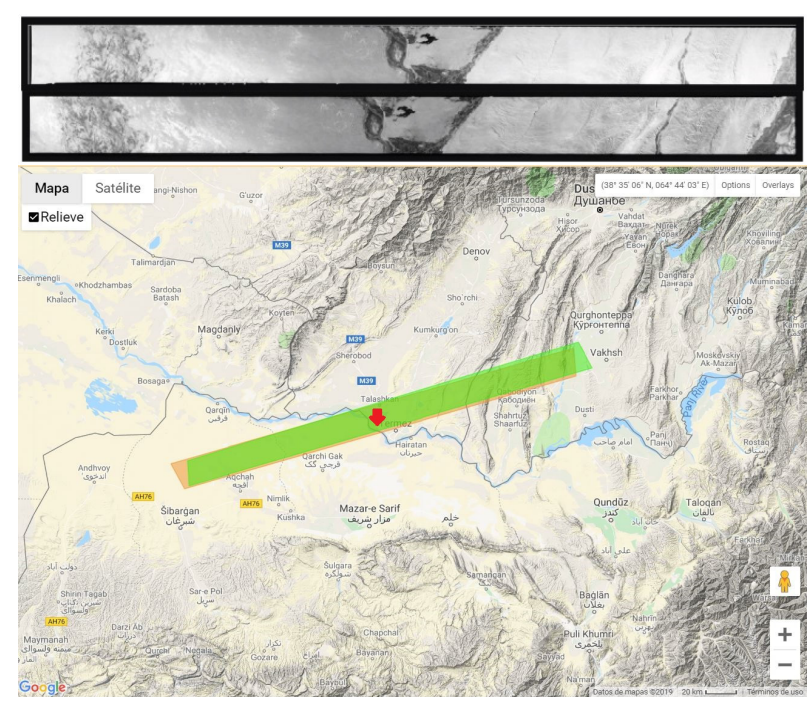

Figure 5: Stereoscopic imagery used in Ancient Termez: DS1012-1039DA163 and DS1012-1039DF157 (above) and their footprints (green and orange) on the ground (below) (USGS-EarthExplorer).

Once the different images had been downloaded, the specific area was cut for processing in the Agisoft Metashape software following the classic workflow:

1. Alignment of photos.

2. GCP identification.

3. Construction of dense point cloud.

4. Construction of digital elevation model.
5. Exporting of results in the coordinate system selected.

The use of this software for archaeological purposes has already been used with CORONA imagery (Watanabe et al. 2017). In both cases the mean of ground control points used were 50 .

Table 1: Table example of the initial exterior orientation parameters of the images.

\begin{tabular}{c|c|c} 
Image & DS1012-1039DA163 & DS1012-1039DF157 \\
\hline $\mathrm{X}_{0}$ & $7.477 .170 \mathrm{~m}$ & $7.489 .300 \mathrm{~m}$ \\
$\mathrm{Y}_{0}$ & $4.485 .140 \mathrm{~m}$ & $4.490 .290 \mathrm{~m}$ \\
$\mathrm{Z}_{0}$ & $185.000 \mathrm{~m}$ & $185.000 \mathrm{~m}$ \\
Yaw & $244^{\circ}$ & $244^{\circ}$ \\
Pitch & $-16,375^{\circ}$ & $-16,375^{\circ}$ \\
Roll & $0^{\circ}$ & $0^{\circ}$
\end{tabular}

\section{Results}

The reconstruction of the Ancient Termez site could not be completed due to the failure in obtaining an old DEM from the CORONA imagery at our disposal (Bellido 2018). However, we were able to reconstruct the current site thanks to the DEM generated from the interpolation of points with altitudinal data extracted from the level curves in the relief map of the site in Ancient Termez (Pidaev 2001; Leriche 2001). Finally, the orthoimage obtained could be projected onto the mesh by unwrapping the UV coordinates with the Blender software. The mapping of this type of coordinates consists of unwrapping the mesh to cover a 3D object with a 2D texture (Fig. 6).

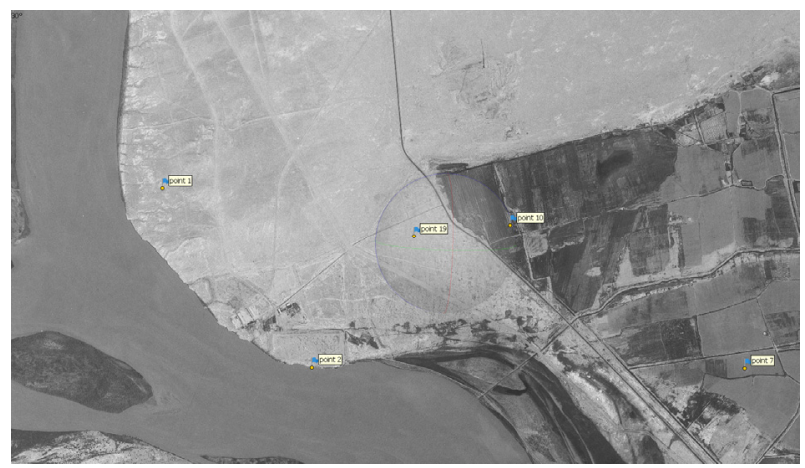

(a)

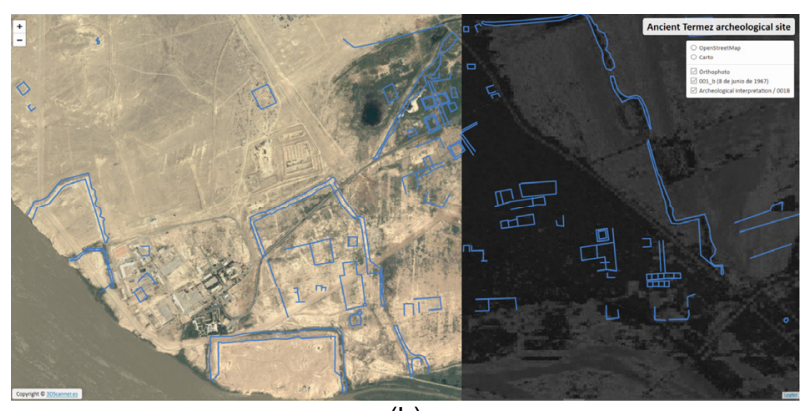

(b)

Figure 6: Comparaison between images: a) CORONA results processed with Metashape software and some GCPs; b) web mapping with different layers to draw hypothetical buried archaeological structures. 
As to the archaeological interpretation, the photointerpretation has been carried out based mainly on the final orthophoto, which has also been georeferenced and tiled for the Leaflet library. In terms of the visual improvement in order to identify the archaeological remains, the best results were obtained with the Simple Local Relief Model. This algorithm is based on eliminating the most notable morphological elements to reveal the smallest scale record (Kokalj and Hesse 2017).

In contrast, the processing of the Kalba area has been able to calculate the DEM with practically the same number of GCPs and the same resolution of the images as the previous site (Fig. 6). The difference between the two large groups of images are the orographic differences in the two sites that produce a better contrast. In the case of Kalba, the final $Z$ error has been higher due to the height difference between the coastal zone and the mountain range, with an approximate slope difference of 500 meters (Table 2).

Table 2: Processing errors and final resolution obtained.

\begin{tabular}{c|c|c|c|c}
$\begin{array}{c}\text { Archaeological } \\
\text { Site }\end{array}$ & $\begin{array}{c}\text { Final } X \\
\text { error } \\
(\mathrm{m})\end{array}$ & $\begin{array}{c}\text { Final } Y \\
\text { error } \\
(\mathrm{m})\end{array}$ & $\begin{array}{c}\text { Final Z } \\
\text { error } \\
(\mathrm{m})\end{array}$ & $\begin{array}{c}\text { Final } \\
\text { resolution } \\
(\mathrm{m})\end{array}$ \\
\hline $\begin{array}{c}\text { Ancient } \\
\text { Termez }\end{array}$ & 3.35 & 3.62 & 4.53 & 2.14 \\
Kalba area & 2.84 & 3.13 & 8.49 & 2.49
\end{tabular}

The reconstructed model in Figure 7 allows us to extract optimal routes from the interior to the coast and above all to compare those areas (currently transformed) where there is a confluence of ravines and concentrations of engravings are likely to be found.

Finally, the results obtained have been uploaded to a new web platform that combines different types of information both in 2D through web mapping and in point clouds with different Potree-related libraries (Boutsi et al. 2019; Schütz 2016) to understand the geometry of each archaeological site. In the case of Termez, only the web mapping viewer has been incorporated with the orthophoto obtained in different layers, in order to be able to overlap the current satellite imagery together with the interpretive drawing of the archaeological structures buried (Fig. 6).

\section{Conclusions}

We have presented a preliminary workflow for the reconstruction of historical landscapes currently lost or modified. The findings have produced uneven results of which the use of this type of imagery cannot be generalised for all areas since this is dependent on the CORONA mission, number of images, overlaps, resolution and control points.

Precise Point Positioning GNSS method is valid but only in capturing a limited number of points for the reconvergence timeout should the signal be lost. Its combination with static GNSS systems has been useful.

Furthermore, this initial study demonstrates that the use of CORONA imagery represents a key source of information in archaeology since in many cases it is virtually the only one available for the reconstruction of the pre-war archaeological landscape or areas modified by urban growth. The use of drones would have provided useful updated information on the current state of the site but would not have allowed the reconstruction of the archaeological landscape fifty years ago. The period from the late 1960s to the early 1970s precedes agricultural mechanisation and urban development and thus many of the sites studied at that time were well-preserved. Above all, it allows for comparing ground anomalies to corroborate buried archaeological structures. However, the spatial resolution and spectral amplitude does not allow a detailed study of archaeological structures of small dimensions.

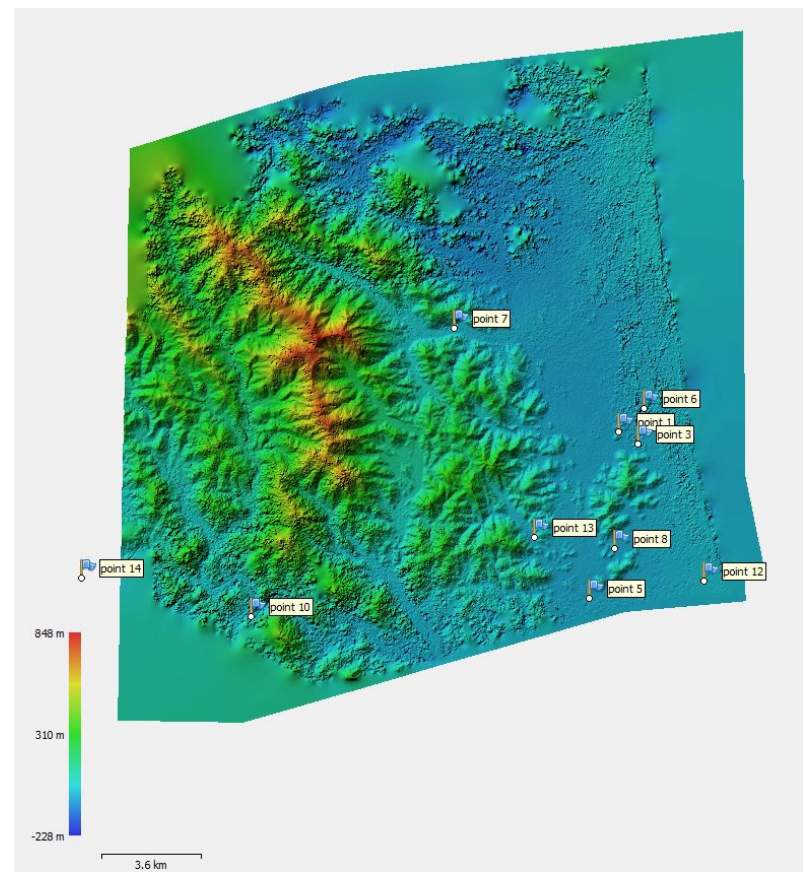

Figure 7: Reconstructed digital elevation model of the Kalba area (UAE) with the GCPs used.

In spite of the great potential of the CORONA imagery, the difficulties involved in correcting their geometry to obtain adjusted spatial information means that it has not been possible to complete the DEM reconstruction of Ancient Termez (Uzbekistan). Likewise, the lack of relief in the area together with the quality of the imagery used have not contributed to the total reconstruction. This difficulty derives from a lack of auxiliary information which was excluded from the declassification process of 1995. The methodology applied here includes a series of auxiliary requirements in order to address this shortcoming in the case study.

In the second archaeological area located in Kalba (UAE), the application results have been satisfactory. In this sense, it has allowed us to reconstruct a digital elevation model for later comparison with the current model and verification of ravine crossings. Experience in this area shows us concentration of rock art engravings in this type of archaeological landscape.

However, in both archaeological sites, the data obtained will be verified on the field in future campaigns.

As to the National Geospatial-Intelligence Agency (NGA) failing to include auxiliary data in the declassification process of the CORONA imagery, this is an issue that should be debated as this information would clearly help 
the scientific community in the use of these images (Galiatsatos 2004; Goosens et al. 2006; Hamandawana et al. 2007; Wierzbicki et al. 2015). Firstly, information on these images and their use would grow exponentially especially in the field of remote sensing, where the processes associated with photogrammetry are not particularly advanced despite being closely related. However, the auxiliary information used throughout the CORONA program to identify common elements is not likely to be compatible with the new technological tools for a camera's interior orientation and the exterior orientation of images in space.

\section{Acknowledgements}

The Termez project was supported by two R\&D\&l projects, CERAC (HAR2016-75133-C3-1-P) led by V.
Martínez and J.M. Gurt, and CONCERAC (HAR201675133-C3-3-P) led by E. Ariño, all funded by the Spanish Ministry of Science, Innovation and Universities. The Palarq Foundation supported the archaeological campaign in Termez in the year 2018. V. Martínez worked on this paper through the post-doctoral research contract Ramón y Cajal (RYC-2014-15789).

Research campaigns in Kalba area have been carried out thanks to the collaboration of SHARJAH ARCHAEOLOGY AUTHORITY (Emirate of Sharjah, United Arab Emirates). This work was developed within the project H2019/HUM-5742 AVIPES-CM (CAMComunidad de Madrid, Spain/ ESF- Fondo Social Europeo).

\section{References}

ALTMAIER, A., and KANY, C., 2002. Digital surface model generation from CORONA satellite images. ISPRS Journal of Photogrammetry and Remote Sensing, 564, pp. 221-235. DOI: 10.1016/S0924-27160200046-1

ANGÁS, J., JASIM, S. A., BEA, M., FARJAS, M., URIBE, P., LANAU, P., and OTERO, X., 2019a. Rock Art recording in Khatm al Melaha (United Arab Emirates): multirange data scanning and web mapping technologies. The International Archives of the Photogrammetry, Remote Sensing and Spatial Information Sciences XLII-2/W15, pp. 85-92. DOI: 10.5194/isprs-archives-XLII-2-W15-85-2019

ANGÁS, J., URIBE, P., ARIÑO, E., GURT, J. M., MARTíNEZ-FERRERAS, V., and PIDAEV, S., 2019b. A multi-scalar photogrammetric recording approach in Termez (Uzbekistan). Int. Arch. Photogramm. Remote Sens. Spatial Inf. Sci., XLII-2/W15, pp. 93-100. DOI: 10.5194/isprs-archives-XLII-2-W15-93-2019.

BELLIDO, A., 2018. Análisis del potencial de las imágenes del programa Corona a través de la reconstrucción del paisaje arqueológico del yacimiento de Termez (Uzbekistán). Trabajo Fin de Máster. Universidad de Zaragoza.

BOUTSI, A.-M., IOANNIDIS, C., and SOILE, S., 2019. Interactive online visualization of complex 3D geometries, Int. Arch. Photogramm. Remote Sens. Spatial Inf. Sci., XLII-2/W9, pp. 173-180. DOI: 10.5194/isprs-archives-XLII-2-W9-1732019

FEKETE, A., 2020. CORONA High-Resolution Satellite and Aerial Imagery for Change Detection Assessment of Natural Hazard Risk and Urban Growth in El Alto/La Paz in Bolivia, Santiago de Chile, Yungay in Peru, Qazvin in Iran, and Mount St. Helens in the USA. Remote Sens. 12(19), pp. 3246. DOI: 10.3390/rs12193246

GALIATSATOS, N., DONOGHUE, D. N. M., and PHILIP, G., 2008. High Resolution Elevation Data Derived from Stereoscopic CORONA Imagery with Minimal Ground Control: An Approach Using Ikonos and SRTM Data. Photogrammetric engineering, 14.

GALIATSATOS, N., 2004. Assessment of the CORONA series of satellite imagery for landscape archaeology: a case study from the Orontes valley, Syria, Durham theses, Durham University. Available at Durham E-Theses Online: http://etheses.dur.ac.uk/281/

GOOSSENS, R., DE WULF, A., BOURGEOIS, J., GHEYLE, W., and WILLEMS, T., 2006. Satellite imagery and archaeology: the example of CORONA in the Altai Mountains. Journal of Archaeological Science, 336, pp. 745-755. DOI: $10.1016 / j$.jas.2005.10.010

GURT ESPARRAGUERA, J. M., ARIÑO GIL, E., MARTíNEZ FERRERAS, V., and PIDAEV, S. R., 2015. The Buddhist occupation of Tchingiz Tepe Termez, Uzbekistan in the Kushan period through the ceramic contexts. Archaeological Research in Asia, 3, pp. 19-33. DOI: 10.1016/j.ara.2015.04.003

HAMANDAWANA, H., ECKARDT, F., and RINGROSE, S., 2007. Proposed methodology for georeferencing and mosaicking Corona photographs. International Journal of Remote Sensing, 281, pp. 5-22. DOI: 10.1080/01431160500104400

HAMMER, E., and UR, J., 2019. Near Eastern Landscapes and Declassified U2 Aerial Imagery. Advances in Archaeological Practice, 7(2), pp. 107-126

KOKALJ, Ž., and HESSE, R., 2017. Airborne Laser Scanning Raster Data Visualization. A Guide to Good Practice. Ljubljana: Založba ZRC.

LERICHE, P., 2001. Termez antique et médiévale. In P. Leriche, S.R. Pidaev, M. Gelin, K. Abdullaev and F. Fourniau ed., La Bactriane au carrefour des routes et des civilisations de l'Asie centrale, pp. 75-99. Maisonneuve and Larose, Paris. 
MARTÍNEZ FERRERAS, V., ARIÑO GIL, E., GURT ESPARRAGUERA, J. M., Aand PIDAEV, S., 2014. The Enclosure of Tchingiz-Tepe Ancient Termez, Uzbekistan during the Kushan and Kushan-Sassanian Periods. Iranica Antiqua, 49, pp. 413-469. DOI: 10.2143/IA.49.0.3009247

PIDAEV, S.R., 2001a. Contribution à I'histoire ancienne de Termez. In P. Leriche, S.R. Pidaev, M. Gelin, K. Abdullaev, F. Fourniau ed., La Bactriane au carrefour des routes et des civilisations de l'Asie centrale, pp. 47-57. Maisonneuve and Larose, Paris.

PIDAEV, S.R, 2001b. Mosquées de quartier dans l'ancciene Tirmidh (Ouzbékistan). Archéologie islamique, pp.61-74.

SCHMIDT, M., GOOSSENS, R., MENZ, G., ALTMAIER, A., and DEVRIENDT, D., 2001. The use of CORONA satellite images for generating a high-resolution digital elevation model. In IGARSS 2001. Scanning the Present and Resolving the Future. Proceedings. IEEE 2001 International Geoscience and Remote Sensing Symposium Cat. No.01CH37217 Vol. 7, pp. 3123-3125. Sydney, NSW, Australia: IEEE. DOI: 10.1109/IGARSS.2001.978277

SCHÜTZ, M., 2016. Potree: Rendering Large Point Clouds in Web Browsers. Faculty of Informatics at the Vienna University of Technology.

SEVARA, C., VERHOEVEN, G., DONEUS, M., and DRAGANITS, E., 2018. Surfaces from the Visual Past: Recovering High-Resolution Terrain Data from Historic Aerial Imagery for Multitemporal Landscape Analysis. Journal of Archaeological Method and Theory, 25(2), pp. 611-642. DOI: 10.1007/s10816-017-9348-9

STOLZE, F., 1882. Persepolis, die achaemenidischen und sasanidischen Denkmäler und Inschriften von Persepolis, Istakhr, Pasargadae, Shāhpūr, 2 vols., Berlin.

UR, J. 2003. CORONA satellite photography and ancient road networks: A northern Mesopotamian case study. Antiquity, 77295, pp. 102-115.

WATANABE, N., NAKAMURA, S., LIU, B., and WANG, N. 2017. Utilization of Structure from Motion for processing CORONA satellite images: Application to mapping and interpretation of archaeological features in Liangzhu Culture, China. Archaeological Research in Asia, 11, pp. 38-50. DOI: 10.1016/j.ara.2017.06.001

WIERZBICKI, D., KRASUSKI, K., and RYKACH, S. P. W. 2015. Estimation of rotation angles based on GPS data from a UX5 Platform. Measurement Automation Monitoring, 61, pp. 516-520. 